Article

\title{
Optimization and in Silico Analysis of a Cold-Adapted Lipase from an Antarctic Pseudomonas sp. Strain AMS8 Reaction in Triton X-100 Reverse Micelles
}

\author{
Fatin Nur Fauzi Ana Abd. Jali1 1,2, Raja Noor Zaliha Raja Abd. Rahman 1,3 (D), \\ Abu Bakar Salleh ${ }^{1,2}$ and Mohd Shukuri Mohamad Ali 1,2,* \\ 1 Enzyme and Microbial Technology Research Center, Universiti Putra Malaysia, Serdang 43400, Selangor, \\ Malaysia; fatinnurfauziana@gmail.com (F.N.F.A.A.J.); rnzaliha@upm.edu.my (R.N.Z.R.A.R.); \\ abubakar@upm.edu.my (A.B.S.) \\ 2 Department of Biochemistry, Faculty of Biotechnology and Biomolecular Science, Universiti Putra Malaysia, \\ Serdang 43400, Selangor, Malaysia \\ 3 Department of Microbiology, Faculty of Biotechnology and Biomolecular Science, Universiti Putra Malaysia, \\ Serdang 43400, Selangor, Malaysia \\ * Correspondence: mshukuri@upm.edu.my; Tel.: +60-3-8947-1053
}

Received: 1 June 2018; Accepted: 11 July 2018; Published: 18 July 2018

\begin{abstract}
A moderate yield of a purified enzyme can be achieved by using the simple technique of reverse micellar extraction (RME). RME is a liquid-liquid extraction method that uses a surfactant and an organic solvent to extract biomolecules. Instead of traditional chromatographic purification methods, which are tedious and expensive, RME using the nonionic surfactant Triton X-100 and toluene is used as an alternative purification technique to purify a recombinant cold-adapted lipase, AMS8. Various process parameters were optimized to maximize the activity recovery of the AMS8 lipase. The optimal conditions were found to be $50 \mathrm{mM}$ sodium phosphate buffer, $\mathrm{pH} 7,0.125 \mathrm{M} \mathrm{NaCl}$, and $0.07 \mathrm{M}$ Triton X-100 in toluene at $10{ }^{\circ} \mathrm{C}$. Approximately $56 \%$ of the lipase activity was successfully recovered. Structural analysis of the lipase in a reverse micelle (RM) was performed using an in silico approach. The predicted model of AMS8 lipase was simulated in the Triton X-100/toluene reverse micelles from 5 to $40^{\circ} \mathrm{C}$. The lid 2 was slightly opened at $10^{\circ} \mathrm{C}$. However, the secondary structure of AMS8 was most affected in the non-catalytic domain compared to the catalytic domain, with an increased coil conformation. These results suggest that an AMS8 lipase can be extracted using Triton X-100/water/toluene micelles at low temperature. This RME approach will be an important tool for the downstream processing of recombinant cold-adapted lipases.
\end{abstract}

Keywords: reverse micellar extraction; cold-adapted lipase; Triton X-100; molecular dynamics simulations

\section{Introduction}

Psychrophilic enzymes obtained from psychrophilic bacteria have been widely exploited because of their high activities at very low temperatures [1,2]. Due to their unique characteristics, these cold-active enzymes offer economic and ecological advantages in biotechnological applications over extremophiles, which operate at higher temperatures [3]. Three major enzymes that have been studied in industrial applications are proteases, lipases, and amylases. However, lipases have attracted special attention from researchers since 1930 [4]. In general, a lipase is a triacylglycerol hydrolase that catalyzes the hydrolysis of triglycerides to free fatty acids and glycerol at the oil-water interface [5]. It also catalyzes bioconversion reactions in non-aqueous media and hydrolyzes organic carbonates in the 
absence of co-factors [6-9]. Cold-active lipases cover a broad spectrum of biotechnological applications, such as additives in detergents (cold washing), an additive in food industries (fermentation, cheese manufacture, bakery, meat tenderizing), bioremediations (Digesters, composting, oil, or xenobiotic biology applications), and molecular biology applications [10-12].

Several conventional purification methods for cold-adapted lipases have been applied for many years in industrial and laboratory procedures $[13,14]$. For example, the lipase KE38 from Pseudomonas fluorescens KE38 was successfully purified using $\left(\mathrm{NH}_{4}\right)_{2} \mathrm{SO}_{4}$ precipitation, Sephadex G-100 and, lastly, ultrafiltration with a recovery of $54.99 \%$ and a 41.13 -fold purification [15]. Likewise, three purification steps were used to purify extracellular LipP from Pseudomonas sp. strain BII-I by using 20-65\% $\left(\mathrm{NH}_{4}\right)_{2} \mathrm{SO}_{4}$ precipitation followed by a diethylaminoethyl (DEAE)-cellulose and graphite column with 38 -fold purification and a recovery of $17 \%$ of the lipase activity [13]. Although a good yield of purified enzyme was obtained from these chromatographic techniques, the production and purification of large amounts of enzyme are often laborious and expensive, which hinders applications for these enzymes [16]. Therefore, a standard method that enables the purification of large amounts of highly pure, active, and stable enzymes is urgently needed. Reverse micellar extraction is one of the alternative purification methods under consideration for continuous downstream processing of bulk enzymes.

A reverse micelle (RM) is a surfactant (hydrophilic head group and hydrophobic tail) that forms a water microemulsion in a nonpolar liquid [17]. It is an ideal model system for confined liquids. This approach has been extensively explored because of their resemblance to biological membranes and their capability for solubilizing enzymes and catalyzing biochemical reactions. The most common applications of RMs are in enzyme catalysis [18], drug delivery [19], nanocluster synthesis [20], and materials development. As an alternative separation practice, RM offers several benefits, such as its ease of operation, low energy requirements, large interfacial area, low cost, and single-stage operation that combines extraction and stripping [21]. Generally, Triton X-114 (a polyoxyethylene detergent, $\left.\mathrm{C}_{14} \mathrm{EO}_{6}\right)$ and members of the alkyl polyoxyethylene family $\left(\mathrm{C}_{m} \mathrm{EO}_{n}\right)$, such as $n$-decyltetraethylene oxide $\left(\mathrm{C}_{10} \mathrm{EO}_{4}\right)$, are used as phase-forming surfactants [22]. The formation of a large interface between the aqueous and nonpolar phases permits reactants that prefer different phases to be conveyed together. Most enzymes are hydrophilic molecules, while substrates may be soluble in nonpolar solutions. The interaction of these molecules occurs when there is an adequate interface between the phases [23]. This partitioning behavior is governed by repulsive, steric, and excluded-volume interactions between the two components [22]. As a result, the interactions between the lipase and surfactant-solvent complexes can be studied with atomic-level detail using molecular dynamics (MD) simulations.

Family 1.3 lipase is a hydrolytic enzyme. It is a bacterial lipase subfamily in which the lipase is mostly produced by Pseudomonas and Serratia sp. [24]. Previously, mesophilic counterparts of the AMS8 lipase, the closed conformation of 1.3 lipases from Pseudomonas sp. MIS38 (PML), were tested with substrate micelles (octane and trilaurin) using MD simulations. Lid 1 of PML was reported to be fully opened in the octane micelles compared to the trilaurin micelles and was followed by the opening of lid 2 in the presence of calcium ions [25]. In addition, interfacial solubilized enzymes, such as lipase and horseradish peroxidase, show high activities at the mixed reverse micellar interface [26]. Cytochrome c was successfully extracted into the Span 60/hexane reverse micelles [27]. Therefore, it is important to verify this experimentally to determine the purified AMS8 and the mode of action of the lipase in the reverse micelles, which may subsequently lead to a higher recovery of activity and degree of purification.

In this work, nonionic surfactant Triton X-100/toluene reverse micelles were used to extract the cold-adapted lipase AMS8 and the procedure was optimized to gain a better production yield. The solvation dynamics (via in silico study) were investigated to visualize the structures and to understand the interaction between the lipase AMS8 and the TX-100/toluene reverse micelles at the molecular level. 


\section{Results and Discussion}

There are many conventional strategies to extract proteins and gain purified enzymes. The cold-adapted lipase AMS8 has been previously purified using affinity and gel filtration chromatography with a final production yield of $23 \%$ and 9.7 -fold purification [28]. Since the lipase recovery was low, attempts have been made to extract lipases using liquid-liquid extraction, especially RME. The most widely reported examples of RME use the ionic surfactant di-2-ethylhexyl sodium sulfosuccinate (AOT) and cetyl trimethyl ammonium bromide (CTAB) for the protein extraction [29-31]. Only a few publications report the application of nonionic surfactants (Triton X-100, Span 60, Tween 85, and Tween 20) [27,32]. Most studies have reported that nonionic surfactants lack the driving force to extract large molecular weight proteins [33]. Affinity RME using cibacron blue (CB)-modified lecithin failed to extract bovine serum albumin (BSA) for this reason [34]. However, one of the valuable properties of nonionic surfactant RME is that, unlike ionic surfactants, it does not denature or alter the structure of the solute during the extraction [33]. This is very important for cold-adapted lipases since these proteins are very conformationally flexible and are easily affected by strong force interactions [10]. Therefore, this study of nonionic surfactant RME for protein extraction should be helpful for understanding the liquid-liquid reverse micellar extraction process. In this study, we purify this cold-adapted enzyme by using an aqueous two-phase system in which reverse micellar extraction has been introduced.

\subsection{Effect of Initial Aqueous Phase $\mathrm{pH}$}

The initial aqueous phase $\mathrm{pH}$ plays a major role in governing the behavior of the protein extraction in the reverse micellar system. The effect of the initial aqueous $\mathrm{pH}$ on the forward extraction of the lipase is shown in Table 1 . The concentration chosen was over the critical micellar concentration $(0.25-0.30 \mathrm{mM})$, which is $0.05 \mathrm{M}$ Triton $\mathrm{X}-100$ in toluene. $\mathrm{NaCl}$ was added to all the initial $\mathrm{pH}$ phases at a concentration of $0.1 \mathrm{M}$. The recovery of the activity was obtained in both organic phase and aqueous phase at $\mathrm{pH} 7$ (3.18\% and 58.84\%, respectively). In the backward extraction, $50 \mathrm{mM}$ Tris- $\mathrm{HCl}$ and $1 \mathrm{M} \mathrm{KCl}$ at $\mathrm{pH} 9$ were selected as the stripping solution (aqueous phase). This is because purified AMS8 lipase has optimum activity at alkaline solution, $\mathrm{pH}$ 9. This buffer was used for all sets of conditions during the optimizations of the forward extraction steps. Thus, the maximum activity recovery for the backward extraction for the aqueous solution was $58.84 \%$. No recovery of the activity was observed at $\mathrm{pH} 8$ to 9 . In the ionic reverse micellar system, the protein extraction was significantly affected by changing the $\mathrm{pH}$ of the solutions. This is due to the electrostatic interaction between the polar head group of the surfactant and the protein surface [35-37]. There is no net charge present in the nonionic surfactant system, but it has a surface charge (positive or negative) at neutral $\mathrm{pH}$. This indicates that the protein extraction was favoured by a weak electrostatic interaction between the surfactant and the solute [38]. Previously, larger proteins have needed a larger number of charged residues on their surface in order to be transferred into RMs, so the larger the protein, the further the $\mathrm{pH}$ of maximal transfer is from the isoelectric point [39]. This theory holds true in the case of AMS8 lipase extraction as its optimal $\mathrm{pH}$ of maximum transfer is 7, which is different from the $\mathrm{pI}$ of AMS8 lipase (4.6).

Table 1. Effect of the initial aqueous $\mathrm{pH}$ on the forward extraction (organic phase) and the backward extraction (aqueous phase) in the Triton X-100/toluene reverse micelles.

\begin{tabular}{cccccc}
\hline Initial Aqueous pHs & pH 5 & pH 6 & pH 7 & pH 8 & pH 9 \\
\hline Phases & \multicolumn{5}{c}{ Activity Recovery (\%) } \\
\hline Organic phase & - & - & 3.176 & - & - \\
Aqueous phase & 5.938 & 5.853 & 58.84 & - & - \\
\hline
\end{tabular}

The reaction mixture (refolded lipase, $0.05 \mathrm{M}$ Triton X-100 in toluene) was incubated at $25^{\circ} \mathrm{C}$ for 15 min under constant stirring $(601 \times g)$. The organic phase was separated by centrifugation at $3607 \times g$ 
for $30 \mathrm{~min}$ at $25^{\circ} \mathrm{C}$. The lipase recovery was carried out by backward extraction using $1 \mathrm{M} \mathrm{KCl}$ in $50 \mathrm{mM}$ Tris- $\mathrm{Cl}$ buffer, $\mathrm{pH} 9$ (volume ratio $1: 1$ ), at $25^{\circ} \mathrm{C}$ for $30 \mathrm{~min}$. The initial total activity of refolded AMS8 lipase (10 mL) at different pHs (pH 5: $1039.5 \mathrm{U} ; \mathrm{pH}$ 6: 7586.2 U; pH 7: $5301.7 \mathrm{U} ; \mathrm{pH}$ 8: $892.8 \mathrm{U}$; $\mathrm{pH}$ 9: $666.22 \mathrm{U}$ ). The lipase was refolded in the different $\mathrm{pHs}$ and their recoveries were set as $100 \%$.

\subsection{Effect of Surfactant Concentration}

Table 2 shows the recovery of activity as a function of the surfactant concentration in the range of 0.01-0.09 M. The initial crude $\mathrm{pH}$ of AMS8 lipase was maintained at $\mathrm{pH} 7$ with $0.1 \mathrm{M} \mathrm{NaCl}$. As the surfactant concentration increased from 0.01 to $0.03 \mathrm{M}$, there was a decline in the recovery of the activity from 118.81 to $77.05 \%$. AMS8 lipase was unsuccessfully extracted at $0.09 \mathrm{M}$ Triton X-100. This may be due to the deassembling of the reverse micelles in the organic phase due to intermicellar collision and a limitation on the solute diffusion due to surfactant aggregates at high surfactant concentrations [33]. However, a small amount of recovery of the lipase activity of $20.75 \%$ was obtained at $0.07 \mathrm{M}$. As AMS8 lipase was assumed to be fully transported into the stripping solution, it was stated that the maximum activity recovery was $14.45 \%$. However, about $6 \%$ of the activity was lost during the phase transfer process from the forward to the backward extraction. Increasing turbidity or cloudiness of the phases with increasing surfactant concentration was observed during the experiment.

Table 2. Effect of the surfactant concentration on the forward extraction (organic phase) and the backward extraction (aqueous phase) in the Triton X-100/toluene reverse micelles.

\begin{tabular}{ccc}
\hline Surfactant Concentration (M) & \multicolumn{2}{c}{ Activity Recovery (\%) } \\
\hline Phases & Organic Phase & Aqueous Phase \\
\hline 0.01 & 118.81 & 8.40 \\
0.03 & 77.05 & 6.43 \\
0.05 & 29.29 & 10.23 \\
0.07 & 20.75 & 14.45 \\
0.09 & 1.62 & 7.72 \\
\hline
\end{tabular}

The reaction mixture (refolded lipase, Triton X-100 in toluene) was incubated at $25^{\circ} \mathrm{C}$ for $15 \mathrm{~min}$ under constant stirring $(601 \times g)$. The organic phase was separated by centrifugation at $3607 \times g$ for $10 \mathrm{~min}$ at $25^{\circ} \mathrm{C}$. The lipase recovery was carried out by backward extraction using $1 \mathrm{M} \mathrm{KCl}$ in $50 \mathrm{mM}$ Tris- $\mathrm{Cl}$ buffer, $\mathrm{pH} 9$, for $30 \mathrm{~min}$. The activity recovery of refolded lipase (control) was set as $100 \%$ $(12,026 \mathrm{U})$.

\subsection{Effect of Ionic Strength}

The effect of the aqueous phase's ionic strength on the enzyme extraction by the organic phase was investigated by varying the concentration of $\mathrm{NaCl}$ from 0.075 to $0.175 \mathrm{M}$ (Table 3). An insignificant decrease in the lipase recovery of organic phase from 85.46 to $81.90 \%$ was observed for 0.075 to $0.125 \mathrm{M} \mathrm{NaCl}$. Then, it keeps decreasing to $52.92 \%$ at $0.175 \mathrm{M} \mathrm{NaCl}$. In the case of the backward extraction, the highest recovery of activity was obtained at $0.125 \mathrm{M} \mathrm{NaCl}(39.47 \%)$. Some studies have shown that a minimum salt concentration enhanced the interactions between the biomolecule and surfactant head groups and reduced the repulsive forces between them [21]. Others have shown that, as the ionic strength increased, the protein uptake capacity of the reverse micelles decreased. The electrostatic effects between the biomolecule and the surfactant existed as varying salt concentrations with the activity recovery [29]. An increased ionic strength led to a reduction of the reverse micellar size, and thus the protein was easily expelled (the squeezing out effect). Decreases in the Debye length might have caused the lower activity recovery at higher salt concentrations [33]. 
Table 3. Effect of the ionic strength on the forward extraction (organic phase) and the backward extraction (aqueous phase) in the Triton X-100/toluene reverse micelles.

\begin{tabular}{ccc}
\hline Salt Concentration (M) & \multicolumn{2}{c}{ Activity Recovery (\%) } \\
\hline Phases & Organic Phase & Aqueous Phase \\
\hline 0.075 & 85.46 & 0.05 \\
0.1 & 85.46 & 34.24 \\
0.125 & 81.90 & 39.47 \\
0.15 & 76.92 & 31.74 \\
0.175 & 52.92 & - \\
\hline
\end{tabular}

The reaction mixture (refolded lipase, $0.07 \mathrm{M}$ Triton X-100 in toluene) was incubated at $25{ }^{\circ} \mathrm{C}$ for 15 min under constant stirring $(601 \times g)$. The organic phase was separated by centrifugation at $3607 \times \mathrm{g}$ for $10 \mathrm{~min}$ at $25^{\circ} \mathrm{C}$. Lipase recovery was carried out by backward extraction using $1 \mathrm{M} \mathrm{KCl}$ in $50 \mathrm{mM}$ Tris- $\mathrm{Cl}$ buffer, $\mathrm{pH}$ 9, for $30 \mathrm{~min}$. The activity recovery of refolded lipase (control) was set as $100 \%(11,193 \mathrm{U})$.

\subsection{Effect of Temperature}

The temperature is a key factor in the formation of nonionic surfactant reverse micelles as compared to the ionic surfactant. Generally, the size of nonionic polyoxyethylene micelles increases with temperature and the growth is more marked at a temperature close to the cloud point [40]. As the micellar size of polyoxyethylene increases, the protein solubility in the organic phase increases to fill the micelles. Luisi et al. (1979) managed to increase the R-chymotrypsin and glucagon transfer yields into an $\mathrm{NH}_{4}{ }^{+} /$chloroform phase to 50 and $100 \%$, respectively [41]. Table 4 shows the effect of temperature on the forward extraction. The optimum forward extraction temperature is $10^{\circ} \mathrm{C}$ with $55.88 \%$ activity recovery. After $10{ }^{\circ} \mathrm{C}$, the lipase activity recovery decreased. Since the cold-adapted lipase AMS8 has high activity at low temperature, at the desired temperature, the enzyme-surfactant interaction increased. Singh and Kishore (2006) have reported that the binding of Triton X-100 to BSA contributes to an increase in the $\mathrm{K}_{1}$ value (by about a factor of 5) with an increase in temperature from 15 to $30^{\circ} \mathrm{C}$. At higher temperatures, proteins tend to lose their structures, leading to modification of the binding site and greater interaction between Triton X-100 and BSA [42]. The initial lipase amount was set at about $30 \mathrm{mg}$, but lipase activity varies (10,000-30,000 U). This affects the activity recovery of the lipase released from the reverse micelles. Even with the same amount released, but it could be active or inactive. Even though the protein concentration increased with temperature, the activity recovery decreased. This is motivated by the high flexibility of the lipase AMS8 at low temperature.

Table 4. Effect of the ionic strength on the forward extraction (organic phase) and the backward extraction (aqueous phase) in the Triton X-100/toluene reverse micelles.

\begin{tabular}{ccc}
\hline Temperature $\left({ }^{\circ} \mathbf{C}\right)$ & \multicolumn{2}{c}{ Activity Recovery $(\%)$} \\
\hline Phases & Organic Phase & Aqueous Phase \\
\hline 5 & 36.79 & 5.44 \\
10 & 43.27 & 55.88 \\
20 & 32.72 & 50.44 \\
30 & 9.12 & 21.20 \\
40 & 14.53 & 13.60 \\
50 & 7.46 & 11.11 \\
\hline
\end{tabular}

The reaction mixture $(0.125 \mathrm{M} \mathrm{NaCl}$ in crude lipase, $0.07 \mathrm{M}$ Triton X-100 in toluene) was incubated for $15 \mathrm{~min}$ under constant stirring (500 rpm). The organic phase was separated by centrifugation at $3000 \mathrm{rpm}$ for $10 \mathrm{~min}$. The lipase recovery was carried out by backward extraction using $1 \mathrm{M} \mathrm{KCl}$ in 
$50 \mathrm{mM}$ Tris-Cl buffer, $\mathrm{pH} 9$, for $30 \mathrm{~min}$. The activity recovery of the refolded lipase (control) was set as $100 \%(27,928 \mathrm{U})$

\subsection{Effect of the Triton X-100/Toluene Reverse Micelles on the Secondary Structure of AMS8}

MD simulations have been extensively used for mimicking surfactant aggregation in micelles [38]. YASARA is a powerful software tool for molecular graphics, modeling, and simulations to perform true interactive real-time simulations with highly accurate force fields on standard personal computers (PCs). It is well-known for its ease of manipulating complex protein-solvent parameters. Studying the surfactant-solvent interfacial structure with biomolecules provides insights into the structural changes enzymes undergo in the micelles. Since the cold-adapted lipase AMS8 has no crystal structure as yet, the closed conformation of the predicted model was used as an initial structure for the MD simulations. The interactions of the protein-reverse micelle complex structures were performed in $10 \mathrm{~ns} \mathrm{MD}$ simulations at different temperatures $\left(5,10,20,25,30\right.$, and $\left.40^{\circ} \mathrm{C}\right)$. To activate the enzyme, a transition from the closed to the open conformation has to occur. This interfacially activated lipase may give insight into how the lid domains act as a door to expose the catalytic triad for substrate accessibility (open conformation) in the presence of Triton X-100/toluene micelles with a temperature effect. Previously, this time-dependent simulation has shown that the second lid (residues 210-222) together with the first lid of the Pseudomonas aeruginosa lipase act as a double door, protecting the hydrophobic catalytic site from the polar solvent [43]. The tolerance of the AMS8 lipase has already been tested with several polar solvents (methanol, ethanol, propanol, and dimethyl sulfoxide-DMSO) and nonpolar solvents (hexane and toluene) in molecular dynamic simulations. Interestingly, the cold-adapted lipase AMS8 strongly interacts with toluene, which is responsible for lid 2 opening. This indicates that the conformational change in the AMS8 lipase from closed to open is influenced by toluene for substrate accessibility [44].

The influence of temperature on the secondary structure of AMS8 lipase in the Triton X-100/ toluene reverse micelles was investigated (Figure 1a). The secondary structures ( $\alpha$-helix, $\beta$-sheet, turn, and coil) were still conserved in the confined liquids. The $\alpha$-helix structure significantly decreases at 25 and $40{ }^{\circ} \mathrm{C}$ compared to the control, with differences of 9.4 and 7.7, respectively. The $\beta$-sheet structure decreased up to 6.5 and 7.2 at $25^{\circ} \mathrm{C}$ and $40{ }^{\circ} \mathrm{C}$, respectively. A slight increase in the turn structure of about 2.3 and 1.3 at 10 and $25^{\circ} \mathrm{C}$ and a sharp increase in the coil conformation at 30 and $20^{\circ} \mathrm{C}$ with differences of 15.4 and 14.9 from the control, respectively, were observed. This may be due to the adaptation of the AMS8 lipase to be more flexible in the confined liquids entrapped in the reverse micelles. Furthermore, these fluctuations were also enhanced by the intrinsic conformational preferences of the different amino acids, which are secondary structure tendencies that redirected the random coil state and the native protein structure association relationship [45]. Therefore, enhanced stability of the protein secondary structure was prompted by hydrogen bonds to the $\alpha$-helices and $\beta$-sheets. From Figure 1b, the total energy required to form hydrogen bonds in the intramolecular AMS8 lipase slightly increased at $25^{\circ} \mathrm{C}$ compared to other temperatures. Since the difference was small, the main residues involved in maintaining the structure, specifically in the catalytic triad and lid conformation (lid 1 and lid 2), were investigated. Unfortunately, the hydrogen bonds of the lid 1 nonpolar residues (Ala-51, Leu-53, Val-54, and Leu-57) had not been maintained from 10 to $30^{\circ} \mathrm{C}$. Throughout the simulations of these temperatures, the interacting lid 2 residues (Asp-157, Val-159, Ser-160, Asp-161, Leu-162, Ala-164, Ala-165, Leu-166, and Gly-167) were maintained after 10 ns of simulation.

Commonly, the residues involved in hydrogen bond formation are bonded to water molecules that mediate ligand interactions with protein polar and charged groups [46]. Surprisingly, in these simulations, nonpolar residues also interacted with water molecules to stabilize the enzyme structure and reverse micelles. As the AMS8 lipase interacted with the surrounding water molecules, the lowest total binding energy for the hydrogen bonds $(4585.17 \mathrm{~kJ} / \mathrm{mol})$ was found at $20^{\circ} \mathrm{C}$. Hence, for $20^{\circ} \mathrm{C}$, the selected residues in the active site (Asp-255) and lid 2 conformation (Glu-148, Leu-150, Asp-153, 
Ile-155, Asp-157, and Asp-161) interacted significantly with water molecules. For the main residue of lid 2, the O-atom of Leu-150 accepts a bond from the O-atom of $\mathrm{H}_{2} \mathrm{O}-1599$ with the lowest binding energy $(17 \mathrm{~kJ} / \mathrm{mol})$ and a distance of $1.8 \AA$. Then, the OE2-atom of Glu-148 accepts a bond from the O-atom of $\mathrm{H}_{2} \mathrm{O}-1577$ with a shortest distance from the actual position of $1.53 \AA$. For the active site, the O-atom of $\mathrm{H}_{2} \mathrm{O}-1523$ donates a bond to the O-atom of Asp-255 with a distance below $2.0 \AA$. In conclusion, the energy of hydrogen bonds is required for enzyme stability at low temperatures for the AMS8 lipase to remain active in the Triton X-100/toluene reverse micelles.

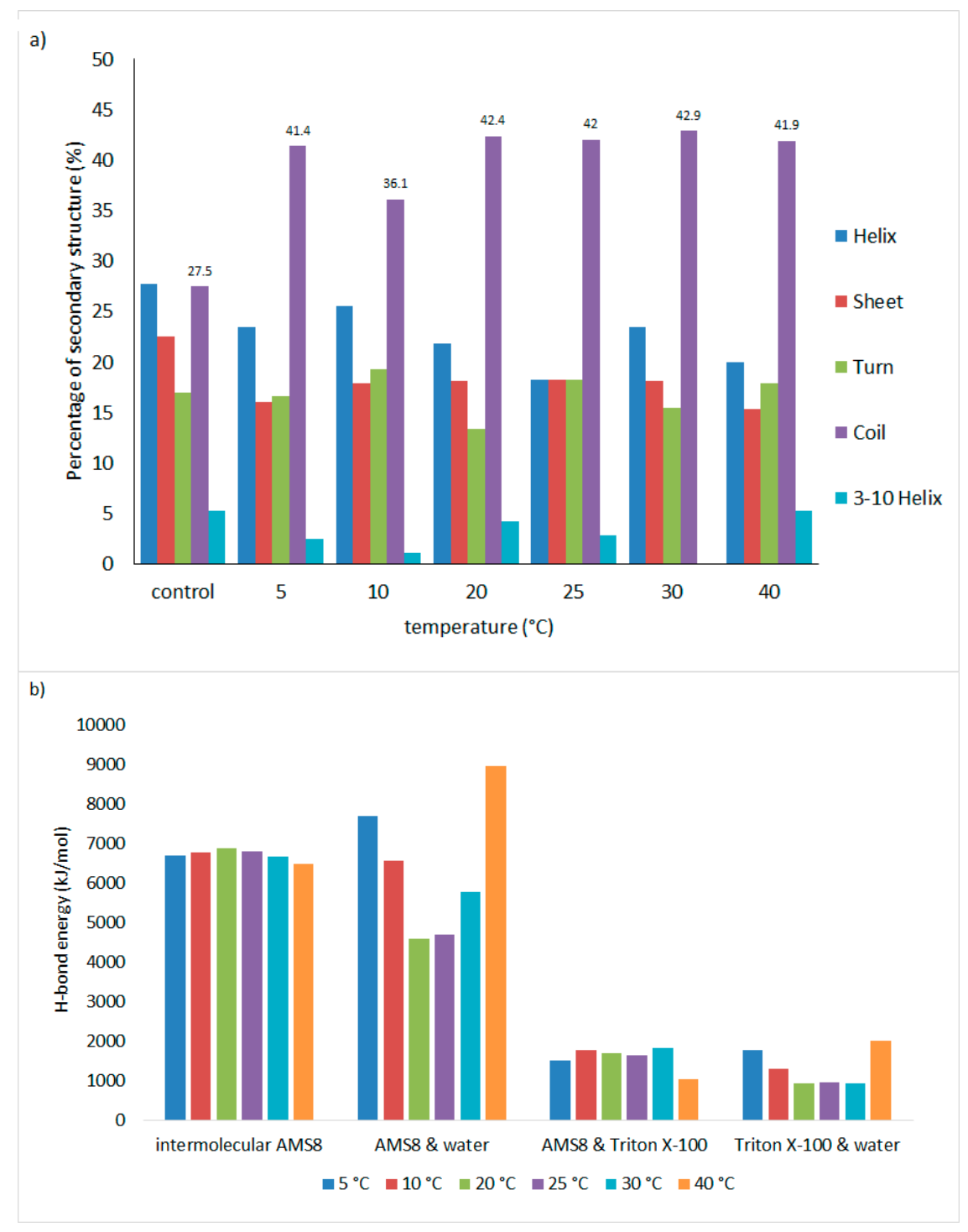

Figure 1. (a) Influence of temperature on the secondary conformation of the AMS8 lipase and (b) the total hydrogen bond energy $(\mathrm{kJ} / \mathrm{mol})$ required to stabilize the AMS8 lipase in Triton X-100/toluene reverse micelles.

\subsection{Stability and Flexibility Analysis of AMS8 in Triton X-100/Toluene Reverse Micelles}

As shown in Figure 2, from 5 to $40{ }^{\circ} \mathrm{C}$, during the beginning of the trajectory the AMS8 lipase simulated at 5,20 , and $25^{\circ} \mathrm{C}$ showed a similar pattern until the end of the simulation $(t=10 \mathrm{~ns})$. An abrupt oscillation from the beginning $(0.948 \AA)$ until 3 ns ( $4.34 \AA$ ) was observed, which suggests that at this point equilibration and thermalization occurred at $10^{\circ} \mathrm{C}$. The root mean square deviations (RMSds) of the AMS8 lipase show minor conformational changes after 3 ns of simulation. However, 
at $30{ }^{\circ} \mathrm{C}$, a gradual fluctuation at 2.6 to $4.1 \mathrm{~ns}$ occurred with an RMSd value of 2.85 to $2.99 \AA$ and further slightly increased until the end of the simulation $(4.2 \AA)$. In contrast, at a higher temperature $\left(40^{\circ} \mathrm{C}\right)$, the deviation value from the beginning of the simulation continued to grow from $0.886 \AA$ to $5.147 \AA$. This suggests that the conformation of the AMS8 lipase remained stable in the Triton X-100/toluene reverse micelles at low to moderate temperatures $\left(5,20\right.$, and $\left.25^{\circ} \mathrm{C}\right)$ as signified by the small deviation in RMSd value between them.

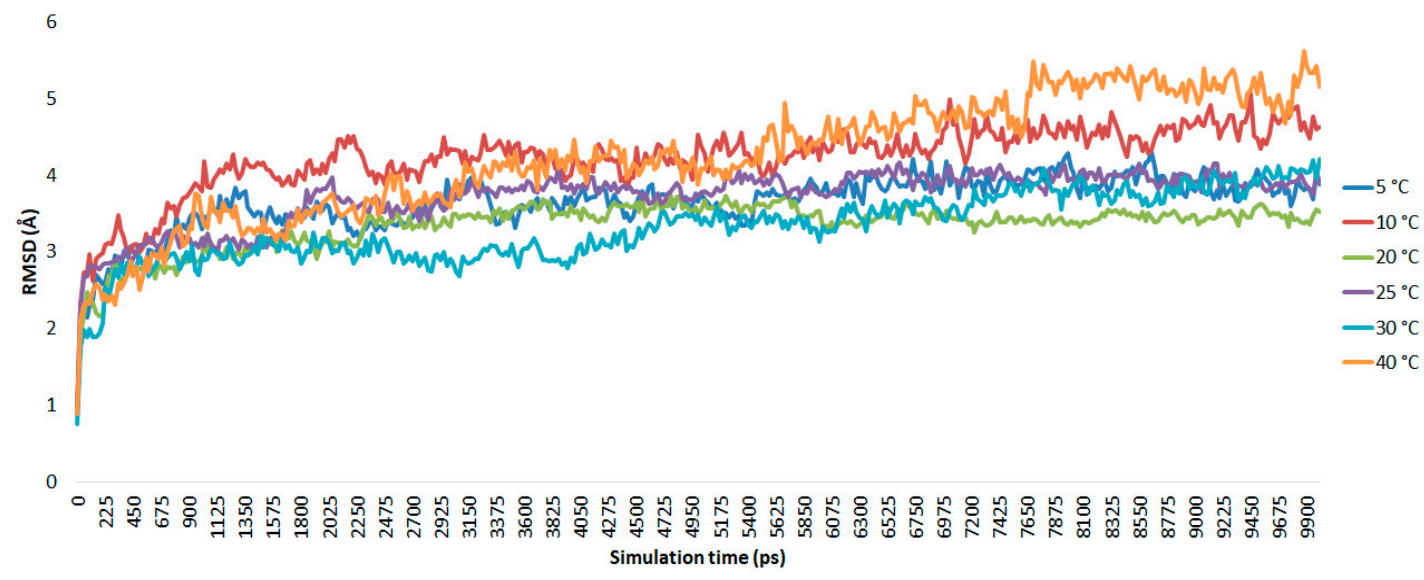

Figure 2. Root mean square deviation (RMSd) of AMS8 atoms as a function of time, simulated in the Triton X-100/toluene micelles at different temperatures.

In the experimental conditions, the AMS8 lipase maintained $43 \%$ of its lipase activity at $10{ }^{\circ} \mathrm{C}$, while at $5{ }^{\circ} \mathrm{C}$ and $20{ }^{\circ} \mathrm{C}$, it remained $36 \%$ and $33 \%$ active, respectively. Thus, the AMS 8 lipase was expected to be stable at these temperatures. However, at $10^{\circ} \mathrm{C}$, it has the highest stagnant RMSd values, probably due to difference from the actual experimental conditions, including the short incubation time and the Triton X-100 concentration. A superposition of the AMS8 lipase simulated at the optimum temperature in the Triton X-100/toluene reverse micelle is shown in Figure 3. A movement of lid 2 from the catalytic site was observed, as the hydrophobic residues disrupt the strong hydrophobic interaction that usually conserves the large hydrophobic cavity, burying the catalytic site.

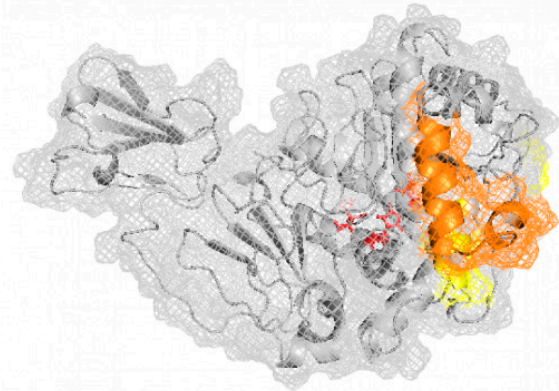

(a)

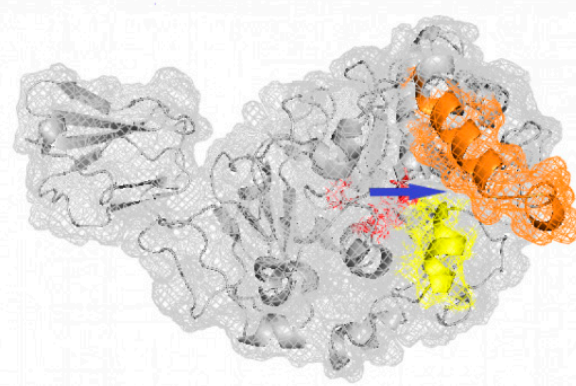

(b)

Figure 3. The conformation of the closed AMS8 lipase before and after simulation in the Triton $\mathrm{X}-100 /$ toluene reverse micelle at $10{ }^{\circ} \mathrm{C}$ (shown in blue arrow). (a) Surface view of the initial structure of the closed AMS8 lipase before the molecular dynamics (MD) simulations. (b) Surface view of the final structure of the open AMS8 lipase after the MD simulations. Lid 1 and lid 2 are colored in yellow and orange, respectively. The active site is colored in red.

For comparison, the AMS8 lipase simulated in water [32] exhibited a stable native-like structure at 0 and $5^{\circ} \mathrm{C}$. At higher temperatures $\left(\geq 25^{\circ} \mathrm{C}\right)$, the globular protein started to lose its native conformation 
to adapt to changes in temperature and the water density (solvent). For the AMS8 lipase simulated in toluene at $25^{\circ} \mathrm{C}$ [44], the RMSd values were as high as $6.76 \AA$ at $10 \mathrm{~ns}$ of simulation. On the other hand, about $55.47 \%$ of the RMSd values were reduced in the Triton X-100/toluene reverse micelles. This shows that the AMS8 lipase is more stable in the reverse micelles than in water and toluene itself. It can be deduced that the cold-adapted protein tends to unfold and denature due to structural elements that confer high motion at a higher temperature $\left(\geq 30^{\circ} \mathrm{C}\right)$.

The flexibility of the enzyme was calculated using the root mean square fluctuation (RMSf) values for each residue throughout the whole trajectories. Figure 4 shows the RMSf per residue for the AMS8 lipase simulated in Triton X-100/toluene reverse micelles at temperatures from 5 to $40{ }^{\circ} \mathrm{C}$. The movement of lid 1 (residues 51-58) can only be seen in the simulation at $30{ }^{\circ} \mathrm{C}$ with the high deviation value of the amino acid Leu49 $(3.19 \AA)$. The lid 1 displacement was not greatly influenced by the temperature switch mechanism with the presence of reverse micelles.

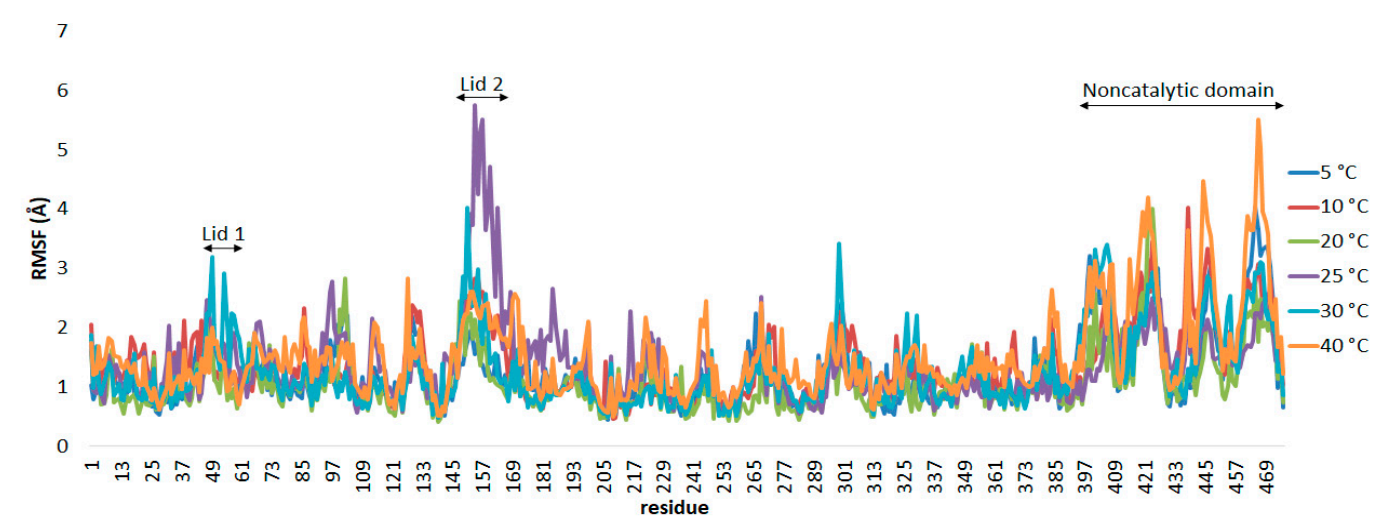

Figure 4. Root mean square fluctuations (RMSf) per residue of the AMS8 atoms.

The conformational transition of lid 2 (residues 148-167) upon contact with the Triton X-100/toluene reverse micelles was clearly perceived during the simulation, as indicated by the RMSf values, which were significantly larger than that of the entire protein. At temperatures of 10 and $20^{\circ} \mathrm{C}$, lid 2 was displaced via the polar residue Ser154, with deviations of $2.832 \AA$ and $2.141 \AA$, respectively. At $25^{\circ} \mathrm{C}$, an Ile151-Thr152 peptide bond was broken, which leads to a higher RMSf value of 3.133-3.918 $\AA$. The whole protein changed significantly beyond the optimum temperature, from 25 to $40^{\circ} \mathrm{C}$, as the heat energy absorbed disrupted protein bonds.

The terminal region is considered to be more flexible than other components of the protein [47]. This can be clearly observed in the water simulation, where the AMS8 lipase gave high RMSf values, particularly in the C-terminal region and the coil conformation (residues 390-476). However, at $25^{\circ} \mathrm{C}$, this region has been significantly reduced. Instead, the lid 2 domain gave the highest RMSf values. In this region, the presence of high glycine residues of repeats-in-toxin (RTX) repeats contributes to the flexibility of the protein structure [48]. The flexibility of the noncatalytic domain in the reverse micelles was reduced by about half as compared to the reverse micelle-free system, particularly at $25^{\circ} \mathrm{C}$ and above. This showed that the stability of the non-catalytic domain improved in the reverse micelles.

In addition, the cold-adapted organic solvent tolerant AT2 lipase and a mutant demonstrated high RMSf values in the N-terminal and C-terminal moieties in water simulations at 25 and $45{ }^{\circ} \mathrm{C}$ [49]. The same trend was found for the thermostable ARM lipase and a mutant, indicating high mobility in the N-terminal region at high temperature [50]. For enzymes simulated in an organic solvent alone, more fluctuations were observed compared to in the reverse micelles. Residues 342-358 and residues 399-424 in the C-terminal region, and residues 78-93 in the N-terminal region of the AMS8 lipase, have lower RMSf values in the reverse micelles than in toluene alone. This shows that the AMS8 lipase is more stable in the reverse micelles than in the organic solvent alone. 


\section{Materials and Methods}

\subsection{Materials}

Polyethylene glycol p-(1,1,3,3-tetramethylbutyl)-phenyl ether (Triton X-100) and toluene were purchased from $\mathrm{R} \& \mathrm{M}$ Chemicals (Essex, UK). Sodium citrate $\left(\mathrm{C}_{6} \mathrm{H}_{5} \mathrm{Na}_{3} \mathrm{O}_{7} \cdot 2 \mathrm{H}_{2} \mathrm{O}\right)$, Tris buffer, disodium hydrogen phosphate $\left(\mathrm{Na}_{2} \mathrm{HPO}_{4}\right)$, sodium dihydrogen phosphate $\left(\mathrm{NaH}_{2} \mathrm{PO}_{4}\right)$, sodium chloride $(\mathrm{NaCl})$, potassium chloride $(\mathrm{KCl})$, calcium chloride $\left(\mathrm{CaCl}_{2}\right)$, sodium hydroxide $(\mathrm{NaOH})$, copper(II) sulphate $\left(\mathrm{Cu}_{2} \mathrm{SO}_{4}\right)$, urea, $p$-Nitrophenol ( $\left.\mathrm{pNP}\right)$, and $p$-nitrophenol palmitate $(p \mathrm{NPP})$ were obtained from Sigma-Aldrich (St. Louis, MO, USA).

DMSO and Arabic gum were sourced from Friendemann Schmidt (Oseterode am harz, Germany). Luria-Bertani (LB) broth and Folin-Ciocalteu reagent were obtained from Merck (Darmstadt, Germany). Isopropylthio- $\beta$-galactoside (IPTG) and ampicillin were purchased from Calbiochem (Billerica, MA, USA). The homogenizer was obtained from Cole-Parmer (Vernon Hills, IL, USA).

\subsection{Preparation of the Recombinant Cold-Adapted Lipase AMS8}

The stock culture of Escherichia coli strain BL21 (DE3) harboring the recombinant plasmid pET32b/AMS8 was stored in $80 \%(v / v)$ glycerol and kept at $-80^{\circ} \mathrm{C}$. The culture was streaked onto LB agar containing ampicillin and incubated at $37^{\circ} \mathrm{C}$ for $12 \mathrm{~h}$. A single colony of E. coli was selected and grown in LB broth containing ampicillin $(50 \mu \mathrm{g} / \mathrm{mL})$ at $37^{\circ} \mathrm{C}$ for $16-18 \mathrm{~h}$ with agitation at $240 \times \mathrm{g}$. The production of the recombinant AMS8 lipase was confirmed by streaking on a Tributyrin LB agar plate containing ampicillin. The plate was incubated at $37^{\circ} \mathrm{C}$ overnight and later the plate was later transferred to $4{ }^{\circ} \mathrm{C}$ for $1-3$ days. A single colony was grown in LB broth $(50 \mathrm{~mL})$ containing ampicillin $(50 \mu \mathrm{g} / \mathrm{mL})$ for the expression. IPTG $(100 \mathrm{mM})$ was added to initiate the expression and incubated for another 16-18 h. The bacterial cells were harvested into a 50-mL Falcon tube and centrifuged at $6654 \times g$, using a centrifuge at $4{ }^{\circ} \mathrm{C}$ (Sigma 3-18K Centrifuge, Washington, DC, USA), for $30 \mathrm{~min}$. The cell pellets were resuspended in $50 \mathrm{mM}$ sodium phosphate buffer with $100 \mathrm{mM} \mathrm{NaCl}$ at pH 7 and lysed by sonication (Branson Sonifier 450) for $6 \mathrm{~min}$. The disrupted cell suspension was centrifuged at $6654 \times g$ for $30 \mathrm{~min}$ to separate the supernatant from the pellet. The pellet was collected and underwent treatment with $8 \mathrm{M}$ urea, $100 \mathrm{mM} \mathrm{NaCl}$, and $10 \mathrm{mM} \mathrm{CaCl}_{2}$ for solubilization at $4{ }^{\circ} \mathrm{C}$ for $1.5 \mathrm{~h}$. Then, the sample was centrifuged at at $6654 \times g$ for $30 \mathrm{~min}$ and the supernatant was subjected to subsequent renaturation by using the 10 -fold dilution method [28].

\subsection{Reverse Micellar Extraction (RME)}

The extraction of the AMS8 was performed using the reverse micellar extraction method reported by Thenmozhi and Basheer (2013) with some modifications [51]. RME consists of a two-step procedure which is forward extraction and backward extraction. Forward extraction involves transferring target biomolecules from an aqueous solution (refolded lipase) to a reverse micellar phase (organic phase) and a subsequent step (backward extraction) involves releasing biomolecules from reversed micelles to the aqueous phase (stripping solution) [22] The organic phase is a mixture of the nonionic surfactant (Triton X-100) and an organic solvent (toluene). The refolded AMS8 lipase was transferred into the organic phase as a forward extraction. The total protein of refolded AMS8 lipase was standardized at about $30 \mathrm{mg}$. Then, $10 \mathrm{~mL}$ of refolded AMS8 lipase (starting sample) was injected into the organic phase (volume ratio 1:1) and homogenized thoroughly for $15 \mathrm{~min}$ at $601 \times \mathrm{g}$. The mixture underwent phase separation by centrifugation for $30 \mathrm{~min}$ at $3607 \times \mathrm{g}$. In the backward extraction, a fresh stripping solution, $50 \mathrm{mM}$ Tris- $\mathrm{HCl}$ containing $1 \mathrm{M} \mathrm{KCl}$ at $\mathrm{pH}$ 9, was injected into the emulsion, stirred for $30 \mathrm{~min}$ at $601 \times \mathrm{g}$, and subjected to the centrifugation for $45 \mathrm{~min}$ at $3607 \times \mathrm{g}$.

Several parameters of the RME were optimized to obtain a better lipase recovery. In the forward extraction, the initial aqueous phase ( $\mathrm{pH} 5-9)$, surfactant concentration (0.01-0.09 M), salt concentration $(0.075-0.175 \mathrm{M})$, and temperature $\left(10-40{ }^{\circ} \mathrm{C}\right)$ were optimized. The lipase activity and the protein content were estimated. 


\subsection{Enzyme Assay}

A spectrophotometric method was used to measure the lipase activity using pNPP as a substrate [52]. With some modifications, $400 \mu \mathrm{L}$ of the $23.96 \mathrm{M}$ pNPP solution was added dropwisely into $3 \mathrm{~mL}$ of $0.05 \mathrm{M}$ sodium phosphate buffer ( $\mathrm{pH} 7$ ), $0.1 \mathrm{~g}$ Arabic gum, and $0.4 \mathrm{~g}$ Triton X-100 with stirring. The lipase extract $(50 \mu \mathrm{L})$ was added to the reaction mixture and assayed at $20{ }^{\circ} \mathrm{C}$ for $5 \mathrm{~min}$. A $10 \%(w / v)$ SDS solution was used to demulsify the reaction mixture from cloudiness. Liberation of pNP was measured at $410 \mathrm{~nm}$ using a Biochrom WPA UV/visible spectrophotometer (Cambridge, $\mathrm{UK}$ ). The control absorbance was deducted from the sample absorbance. One unit (U) of lipase activity was defined as $1.0 \mathrm{nmol}$ of pNP released per min under the conditions stated above.

\subsection{Estimate of Protein Content}

The estimate of protein content was adapted from Chandra et al. (1975) using bovine serum albumin (BSA) as a standard [53]. A BSA standard curve was plotted using a protein solution in the range of $0-2000 \mu \mathrm{g}$ of protein. For the sample, $1 \mathrm{~mL}$ was added to $5 \mathrm{~mL}$ of the alkaline copper reagent and vortexed to mix well. After $10 \mathrm{~min}, 0.5 \mathrm{~mL}$ of $1 \mathrm{~N}$ Folin-Ciocalteu reagent was mixed and left for detergent precipitation for at least $20 \mathrm{~min}$. Then, it was centrifuged at $1202 \times \mathrm{g}$ for $10 \mathrm{~min}$, and the absorbance was measured at $700 \mathrm{~nm}$ against a reagent blank.

\subsection{Activity Recovery Estimation}

The activity recovery of the extracted lipase was calculated according to the following equation:

$$
\text { Activity recovery }(\%)=\frac{\text { lipase activity in organic phase after forward extraction or aqueous phase after backward extracttion }\left(\frac{U}{m l}\right)}{\text { lipase activity in refolded lipase activity }\left(\frac{U}{m l}\right)}
$$

\subsection{Computational Analysis}

\subsubsection{Protein Sequence and Predicted Model of the AMS8 Lipase}

The three-dimensional (3D) structure of cold-adapted lipase isolated from Pseudomonas fluorescens strain AMS8 (GenBank accession No: ADM87309.1) was used in the molecular dynamic simulations. The predicted model of the AMS8 lipase was acquired by superimposing the crystal structures of the Serratia marcescens lipase (PDB ID: 2qua) and the Pseudomonas sp. MIS38 lipase (PDB ID: 2z8x) due to their similar sequence identity [54].

\subsubsection{Simulation Parameters}

The MD simulations were performed on the predicted model of the AMS8 lipase in the closed conformation with the calcium ions and zinc ion intact. The AMS8 lipase was used as the starting structure to analyze conformational changes in AMS8 in the presence of hydrocarbon (toluene and Triton X-100) micelles and water. The PDB coordinates for toluene and Triton X-100 were generated from PUBCHEM (https:/ / pubchem.ncbi.nlm.nih.gov/compound/). A varied simulation box $(X=77.49-95.05 \AA, Y=70.98-75.48 \AA, Z=66.30-66.78 \AA)$ was filled with the toluene density appropriate to the temperature and Triton X-100 (100 molecules) was added randomly around AMS8 together with water and $\mathrm{NaCl}$. The MD simulations were completed with the YASARA Structure (version 11.3.22, Krieger, Vienna, Austria) software [55,56]. Energy minimizations were performed using the steepest descent method for about 2000 steps before the simulation started with the fixed AMS8 lipase model. The protein-solvent-surfactant simulation systems were executed at 278-313 K and 1 bar pressure under the steepest descent parameters. The total system size was $\sim 45,000$ atoms with all the molecules and AMS8 lipase filled in the simulation box. The AMBER03 force field with a cut off of $10.846 \AA$ was used in the simulation. The lipase was studied using 400 saved simulation steps, with 40 picoseconds, representing 1 nanosecond. The MD simulations were permitted to run until $10 \mathrm{~ns}$. 


\subsubsection{Simulation Analysis}

The stability and flexibility of a residue in the enzyme at a given simulated time were obtained from the root mean square deviation (RMSd) and the root mean square fluctuation (RMSf). These revealed deviations from the native enzyme structure, showing an interruption of the molecular forces of the molecules. The $\alpha$-helix and $\beta$-sheet, as well as the distance between the lid domains and the catalytic residues, were obtained from the simulation. The protein simulation snapshots in the Triton X-100/toluene reverse micelles obtained from various timelines were aligned in a parallel arrangement (by superimposing the structures), showing the movement of the lid, using the open-source PyMOL Molecular Graphics System Version 1.1 (2009) software developed by Schrödinger, Inc (https:/ / pymol. $\operatorname{org} / 2 /)$.

\section{Conclusions}

Optimized Triton X-100/toluene reverse micellar extraction conditions for confinement of the cold-adapted lipase AMS8 were achieved for the first time in this study. The effects of the process parameters, such as the $\mathrm{pH}$ of the initial aqueous phase ( $\mathrm{pH} 7)$, the Triton $\mathrm{X}-100$ concentration $(0.07 \mathrm{M})$, the $\mathrm{NaCl}$ concentration $(0.125 \mathrm{M})$, and the temperature $\left(10^{\circ} \mathrm{C}\right)$ for the forward extraction were successfully explored. These conditions gave a lipase activity recovery of $55.88 \%$. In addition, MD simulations offered structural insight about the AMS8 lipase in the Triton X-100/toluene reverse micelles. At different temperatures, the opening of lid 2 was triggered from 10 to $20^{\circ} \mathrm{C}$, whereas lid 1 did not significantly deviate from the active site. This showed that the AMS 8 lipase was more stable in the reverse micelles than in water or toluene itself. Thus, this protocol can be a promising approach due the low cost and reduced time consumption for the purification of the recombinant cold-adapted lipase AMS8. Further improvements to this lipase extraction can be achieved in the future by optimizing the backward extraction.

Author Contributions: Conceptualization, F.N.F.A.A.J. and M.S.M.A.; Methodology, F.N.F.A.A.J. and M.S.M.A.; Software, M.S.M.A.; Validation, M.S.M.A. and A.B.S.; Formal Analysis, F.N.F.A.A.J., M.S.M.A., and A.B.S.; Investigation, F.N.F.A.A.J.; Resources, M.S.M.A., R.N.Z.R.A.R., and A.B.S.; Data Curation, F.N.F.A.A.J. and M.S.M.A.; Writing (Review and Editing), M.S.M.A. and A.B.S.; Visualization, F.N.F.A.A.J.; Supervision, M.S.M.A., R.N.Z.R.A.R., and A.B.S.; Project Administration, M.S.M.A.; Funding Acquisition, M.S.M.A., R.N.Z.R.A.R., and A.B.S.

Acknowledgments: This research and F.N.F.A.A.J schorlarship were supported by Graduate Research Fellowship (GRF) fund from Universiti Putra Malaysia.

Conflicts of Interest: The authors declare no conflict of interest.

\section{References}

1. Cavicchioli, R.; Charlton, T.; Ertan, H.; Mohd Omar, S.; Siddiqui, K.S.; Williams, T.J. Biotechnological uses of enzymes from psychrophiles. Microb. Biotechnol. 2011, 4, 449-460. [CrossRef] [PubMed]

2. De Maayer, P.; Anderson, D.; Cary, C.; Cowan, D.A. Some like it cold: Understanding the survival strategies of psychrophiles. EMBO Rep. 2014, 15, 508-517. [CrossRef] [PubMed]

3. Karan, R.; Capes, M.D.; Dassarma, S. Function and biotechnology of extremophilic enzymes in low water activity. Aquat. Biosyst. 2012, 8, 4. [CrossRef] [PubMed]

4. Daiha, K.D.G.; Angeli, R.; de Oliveira, S. D Are Lipases Still Important Biocatalysts? A Study of Scientific Publications and Patents for Technological Forecasting. PLoS ONE 2015, 10, e0131624. [CrossRef] [PubMed]

5. Gupta, R.; Gupta, N.; Rathi, P. Bacterial lipases: An overview of production, purification and biochemical properties. Appl. Microbiol. Biotechnol. 2004, 64, 763-781. [CrossRef] [PubMed]

6. Pandey, A.; Benjamin, S.; Soccol, C.R.; Nigam, P.; Krieger, N.; Soccol, V.T. The realm of microbial lipases in biotechnology. Biotechnol. Appl. Biochem. 1999, 29, 119-131. [CrossRef] [PubMed]

7. Sharma, R.; Chisti, Y.; Chand, U.; Banerjee, U.C. Production, Purification, Characterization, and Applications of Lipases. Biotechnol. Adv. 2001, 19, 627-662. [CrossRef] 
8. Dutra, J.C.V.; da Terzi, S.C.; Bevilaqua, J.V.; Damaso, M.C.T.; Couri, S.; Langone, M.A.P.; Senna, L.F. Lipase production in solid-state fermentation monitoring biomass growth of Aspergillus niger using digital image processing. Appl. Biochem. Biotechnol. 2008, 147, 63-75. [CrossRef] [PubMed]

9. Rajendran, A.; Palanisamy, A.; Thangavelu, V. Lipase Catalyzed Ester Synthesis for Food Processing Industries. Braz. Arch. Biol. Technol. 2009, 52, 207-219. [CrossRef]

10. Joseph, B.; Ramteke, P.W.; Thomas, G. Cold active microbial lipases: Some hot issues and recent developments. Biotechnol. Adv. 2008, 26, 457-470. [CrossRef] [PubMed]

11. Siddiqui, K.S.; Cavicchioli, R. Cold-Adapted Enzymes. Annu. Rev. Biochem. 2006, 75, 403-433. [CrossRef] [PubMed]

12. Gerday, C.; Aittaleb, M.; Bentahir, M.; Chessa, J.-P.; Claverie, P.; Collins, T.; D'Amico, S.; Dumont, J.; Garsoux, G.; Georlette, D.; et al. Cold-adapted enzymes: From fundamentals to biotechnology. Trends Biotechnol. 2000, 18, 103-107. [CrossRef]

13. Choo, D.W.; Kurihara, T.; Suzuki, T.; Soda, K.; Esaki, N. A cold-adapted lipase of an Alaskan psychrotroph, Pseudomonas sp. strain B11-1: Gene cloning and enzyme purification and characterization. Appl. Environ. Microbiol. 1998, 64, 486-491. [PubMed]

14. Dong, H.; Gao, S.; Han, S.-P.; Cao, S.-G. Purification and characterization of a Pseudomonas sp. lipase and its properties in non-aqueous media. Biotechnol. Appl. Biochem. 1999, 30, 251-256. [CrossRef] [PubMed]

15. Gökbulut, A.A.; Arslanoğlu, A. Purification and biochemical characterization of an extracellular lipase from psychrotolerant Pseudomonas fluorescens KE38. Turkish J. Biol. 2013, 37, 538-546. [CrossRef]

16. Tufvesson, P.; Lima-Ramos, J.; Nordblad, M.; Woodley, J.M. Guidelines and cost analysis for catalyst production in biocatalytic processes. Org. Process Res. Dev. 2011, 15, 266-274. [CrossRef]

17. Fang, Y.Y.; Zeng, G.M.; Huang, J.H.; Liu, J.X.; Xu, X.M.; Xu, K.; Qu, Y.H. Micellar-enhanced ultrafiltration of cadmium ions with anionic-nonionic surfactants. J. Memb. Sci. 2008, 320, 514-519. [CrossRef]

18. Sykora, J.; Brezovsky, J.; Koudelakova, T.; Lahoda, M.; Fortova, A.; Chernovets, T.; Chaloupkova, R.; Stepankova, V.; Prokop, Z.; Smatanova, I.K.; et al. Dynamics and hydration explain failed functional transformation in dehalogenase design. Nat. Chem. Biol. 2014, 10, 428-430. [CrossRef] [PubMed]

19. Marques, B.S.; Nucci, N.V.; Dodevski, I.; Wang, K.W.C.; Athanasoula, E.A.; Jorge, C.; Wand, A.J. Measurement and Control of pH in the Aqueous Interior of Reverse Micelles. J. Phys. Chem. B 2014, 118, 2020-2031. [CrossRef] [PubMed]

20. Mills, A.J.; Wilkie, J.; Britton, M.M. NMR and Molecular Dynamics Study of the Size, Shape, and Composition of Reverse Micelles in a Cetyltrimethylammonium Bromide (CTAB)/n-Hexane/Pentanol/Water Microemulsion. J. Phys. Chem. B 2014, 118, 10767-10775. [CrossRef] [PubMed]

21. Bhavya, S.G.; Priyanka, B.S.; Rastogi, N.K. Reverse micelles-mediated transport of lipase in liquid emulsion membrane for downstream processing. Biotechnol. Prog. 2012, 28, 1542-1550. [CrossRef] [PubMed]

22. Mazzola, P.G.; Lopes, A.M.; Hasmann, F.A.; Jozala, A.F.; Penna, T.C.V.; Magalhaes, P.O.; Rangel-Yagui, C.O.; Pessoa, A. Liquid-liquid extraction of biomolecules: An overview and update of the main techniques. J. Chem. Technol. Biotechnol. 2008, 83, 143-157. [CrossRef]

23. Faeder, J.; Ladanyi, B.M. Solvation dynamics in reverse micelles: The role of headgroup-solute interactions. J. Phys. Chem. B 2005, 109, 6732-6740. [CrossRef] [PubMed]

24. Rahman, R.N.Z.R.A.; Baharum, S.N.; Basri, M.; Salleh, A.B. High-yield purification of an organic solvent-tolerant lipase from Pseudomonas sp. strain S5. Anal. Biochem. 2005, 341, 267-274. [CrossRef] [PubMed]

25. Angkawidjaja, C.; Matsumura, H.; Koga, Y.; Takano, K.; Kanaya, S. X-ray crystallographic and MD simulation studies on the mechanism of interfacial activation of a family I.3 lipase with two lids. J. Mol. Biol. 2010, 400, 82-95. [CrossRef] [PubMed]

26. Shome, A.; Roy, S.; Das, P.K. Nonionic surfactants: A key to enhance the enzyme activity at cationic reverse micellar interface. Langmuir 2007, 23, 4130-4136. [CrossRef] [PubMed]

27. Naoe, K.; Ura, O.; Hattori, M.; Kawagoe, M.; Imai, M. Protein extraction using non-ionic reverse micelles of Span 60. Biochem. Eng. J. 1998, 2, 113-119. [CrossRef]

28. Ganasen, M.; Yaacob, N.; Rahman, R.N.Z.R.A.; Leow, A.T.C.; Basri, M.; Salleh, A.B.; Ali, M.S.M. Cold-adapted organic solvent tolerant alkalophilic family I.3 lipase from an Antarctic Pseudomonas. Int. J. Biol. Macromol. 2016, 92, 1266-1276. [CrossRef] [PubMed] 
29. Hebbar, H.U.; Raghavarao, K.S.M.S. Extraction of bovine serum albumin using nanoparticulate reverse micelles. Process Biochem. 2007, 42, 1602-1608. [CrossRef]

30. Chen, M.; Chen, M.; Lee, P.; Cheng, L.; Huang, L.; Lai, C.; Huang, K. transport between an aqueous phase and a CTAB/hexanol-octane reversed micellar phase. Biochem. Eng. J. 2010, 53, 121-130. [CrossRef]

31. Shiomori, K.; Isa, Y.; Kuboi, R. Extraction Characteristic of Bovine Serum Albumin Using Sodium Bis (2-Ethylhexyl) Sulfosuccinate Reverse Micelles. J. Ferment. Bioeng. 1998, 86, 581-587. [CrossRef]

32. Vasudevan, M.; Wiencek, J.M. Mechanism of the extraction of proteins into Tween 85 nonionic microemulsions. Ind. Eng. Chem. Res. 1996, 35, 1085-1089. [CrossRef]

33. Hebbar, H. Reverse Micellar Extraction for Downstream Processing of Enzymes/Proteins. Ph.D. Thesis, University of Mysore, Karnataka, India, December 2007.

34. Sun, Y.; Ichikawa, S.; Sugiura, S.; Furusaki, S. Affinity extraction of proteins with a reversed micellar system composed of Cibacron Blue-modified lecithin. Biotechnol. Bioeng. 1998, 58, 58-64. [CrossRef]

35. Gonçalves, A.M.; Serro, A.P.; Aires-Barros, M.R.; Cabral, J.M.S. Effects of ionic surfactants used in reversed micelles on cutinase activity and stability. BBA-Protein Struct. Mol. Enzymol. 2000, 1480, 92-106. [CrossRef]

36. Forney, C.E.; Glatz, C.E. Extraction of charged fusion proteins in reversed micelles: Comparison between different surfactant systems. Biotechnol. Prog. 1995, 11, 260-264. [CrossRef] [PubMed]

37. Abel, S.; Sterpone, F. Molecular modeling and simulations of AOT-water reverse micelles in isooctane: Structural and dynamic properties. J. Phys. Chem. B 2004, 108, 19458-19466. [CrossRef]

38. Vasudevan, M.; Tahan, K.; Wiencek, J.M. Surfactant structure effects in protein separations using nonionic microemulsions. Biotechnol. Bioeng. 1995, 46, 99-108. [CrossRef] [PubMed]

39. Hilhorst, R.; Fijneman, P.; Heering, D.; Wolbert, R.B.G.; Dekker, M.; van't Riet, K.; Bijsterbosch, B.H. Protein extraction using reversed micelles. Pure Appl. Chem. 1992, 64, 1765-1770. [CrossRef]

40. Patel, U.; Dharaiya, N.; Parikh, J.; Aswal, V.K.; Bahadur, P. Effect of amphiphilic and non-amphiphilic polymers on micellar behaviour of nonionic surfactant Triton X-100. Colloids Surf. A Physicochem. Eng. Asp. 2015, 481, 100-107. [CrossRef]

41. Pires, M.J.; Cabral, J.M.S. Liquid-Liquid Extraction of Proteins with Reversed Micelles. Biotechnol. Prog. 1996, 12, 290-301. [CrossRef]

42. Singh, S.K.; Kishore, N. Thermodynamic insights into the binding of triton $X-100$ to globular proteins: A calorimetric and spectroscopic investigation. J. Phys. Chem. B 2006, 110, 9728-9737. [CrossRef] [PubMed]

43. Cherakisvada, S.L.; Seshasayee, A.S.H.; Raghureaihaft, K.; Anisheity, S.R.; Penrsathw, G. Evidence of a double-lid movement in pseudomonas lipase: Insights from molecular dynamics simulations. PLoS Comput. Biol. 2005, 1, 0182-0189. [CrossRef]

44. Yaacob, N.; Mohamad Ali, M.S.; Salleh, A.B.; Abdul Rahman, R.N.Z.R.; Leow, A.T.C. Toluene promotes lid 2 interfacial activation of cold active solvent tolerant lipase from Pseudomonas fluorescens strain AMS8. J. Mol. Graph. Model. 2016, 68, 224-235. [CrossRef] [PubMed]

45. Smith, L.J.; Fiebig, K.M.; Schwalbe, H.; Dobson, C.M. The concept of a random coil. Residual structure in peptides and denatured proteins. Fold. Des. 1996, 1, R95-R106. [CrossRef]

46. Worth, C.L.; Blundell, T.L. On the evolutionary conservation of hydrogen bonds made by buried polar amino acids: The hidden joists, braces and trusses of protein architecture. BMC Evol. Biol. 2010, 10, 161. [CrossRef] [PubMed]

47. Iwakura, M.; Honda, S. Stability and reversibility of thermal denaturation are greatly improved by limiting terminal flexibility of Escherichia coli dihydrofolate reductase. J. Biochem. 1996, 119, 414-420. [CrossRef] [PubMed]

48. Evdokimov, A.G.; Pokross, M.; Walter, R.; Mekel, M.; Cox, B.; Li, C.; Bechard, R.; Genbauffe, F.; Andrews, R.; Diven, C.; et al. Engineering the catalytic domain of human protein tyrosine phosphatase $\beta$ for structure-based drug discovery. Acta Crystallogr. Sect. D Biol. Crystallogr. 2006, 62, 1435-1445. [CrossRef] [PubMed]

49. Kamarudin, N.H.A.; Abdul Rahman, R.N.Z.R.; Mohamad Ali, M.S.; Leow, T.C.; Basri, M.; Salleh, A.B. Unscrambling the effect of C-terminal tail deletion on the stability of a cold-adapted, organic solvent stable lipase from Staphylococcus epidermidis AT2. Mol. Biotechnol. 2014, 56, 747-757. [CrossRef] [PubMed]

50. Salleh, A.B. The Role of Arg157Ser in Improving the Compactness and Stability of ARM Lipase. J. Comput. Sci. Syst. Biol. 2012, 5, 39-46. [CrossRef] 
51. Basheer, S.A.; Thenmozhi, M. Reverse Micellar Separation of Lipases: A Critical Review. Int. J. Chem. Sci. 2010, 8, 57-67.

52. Macris, J.B.; Kourentzi, E.; Hatzinikolaou, D.G. Studies on localization and regulation of lipase production by Aspergillus niger. Process Biochem. 1996, 31, 807-812. [CrossRef]

53. ChandraRajan, J.; Klein, L. Lowry assay of dilute protein solutions containing high concentrations of Triton X-100. Anal. Biochem. 1975, 69, 632-636. [CrossRef]

54. Angkawidjaja, C.; You, D.; Matsumura, H.; Kuwahara, K.; Koga, Y.; Takano, K.; Kanaya, S. Crystal structure of a family I.3 lipase from Pseudomonas sp. MIS38 in a closed conformation. FEBS Lett. 2007, 581, 5060-5064. [CrossRef] [PubMed]

55. Krieger, E.; Koraimann, G.; Vriend, G. Increasing the precision of comparative models with YASARA NOVA-A self-parameterizing force field. Proteins Struct. Funct. Genet. 2002, 47, 393-402. [CrossRef] [PubMed]

56. Mohamad Ali, M.S.; Mohd Fuzi, S.F.; Ganasen, M.; Abdul Rahman, R.N.Z.R.; Basri, M.; Salleh, A.B. Structural adaptation of cold-active RTX lipase from Pseudomonas sp. strain AMS8 revealed via homology and molecular dynamics simulation approaches. Biomed Res. Int. 2013, 2013, 925373. [CrossRef] [PubMed]

(C) 2018 by the authors. Licensee MDPI, Basel, Switzerland. This article is an open access article distributed under the terms and conditions of the Creative Commons Attribution (CC BY) license (http:/ / creativecommons.org/licenses/by/4.0/). 